\title{
Jacek Strojny
}

Wiestaw Musial

Uniwersytet Rolniczy im. Hugona Koltątaja w Krakowie

\section{Obszary wiejskie w systemie ekonomiczno-spolecznym państw Unii Europejskiej}

\section{RURAL AREAS IN THE SOCIO-ECONOMIC SYSTEM OF EU COUNTRIES}

\begin{abstract}
W opracowaniu podjęto problem identyfikacji i oceny obszarów wiejskich oraz pośrednich wiejsko-miejskich krajów Unii Europejskiej. Dla wybranych czterech zmiennych opisujacych ich, powierzchnię, udziat ludności, udzial zatrudnionych $i$ wypracowanq wartość dodanq brutto (GVA) wykonano analizy tabelaryczne, analize skupień oraz dokonano dyskryminacji informacji statystycznej przy zastosowaniu techniki drzew klasyfikacyjnych. Przeprowadzone badania wskazały na wielowymiarowe zróżnicowanie obszarów wiejskich oraz ich duże, choć zróżnicowane znaczenie w ekonomii poszczególnych krajów. Na wydzielonych stricte obszarach wiejskich krajów UE, które stanowiq 49,7\% powierzchni, zamieszkuje 34,7\% ludności, 26,7\% znajduje zatrudnienie na wsi, a udziat $w$ wypracowanej wartości dodanej wynosi 13\%. Analiza taksonomiczna skutkowała wyodrębnieniem trzech grup (skupień) liczacych po osiem państw. Polska $w$ tej kompleksowej ocenie obszarów wiejskich jest podobna do Czech, Danii, Francji, Łotwy i Niemiec.
\end{abstract}

Słowa kluczowe: obszary wiejskie UE, ludność na obszarach wiejskich, wartość dodana brutto (GVA)

JEL Codes: Q18, R14, Q15

\section{Wprowadzenie}

Zainteresowanie nauk ekonomicznych obszarami wiejskimi ma w Europie długą tradycje, lecz badania wskazuja, że ich wcześniejsze funkcje gospodarcze i społeczne daleko odbiegały od obecnych. Do końca XIX wieku niemal na całym kontynencie europejskim wsie stanowiły naturalne skupiska ludności zajmujących się rolnictwem i rzemiosłem, głównie z nim związanym. W krajach podlegających silnym procesem industrializacji wsie, gdy były położone w pobliżu ośrodków przemysłowych, zwykle miast, było często wchłaniane urbanistycznie i poddawane selekcji demograficznej celem pozyskania siły roboczej dla rozwijającego się przemysłu. Z czasem wsie stanowiły, także miejsca lokalizacji rozbudowującego się od XIX wieku agrobiznesu, w tym głównie drobnego przetwórstwa żywności, produkcji materiałów budowlanych i narzędzi rolniczych. Obecnie także obszary wiejskie przechodzą intensywne przeobrażenia, których charakter jest regionalnie wysoce zróżnicowany ekonomicznie, społecznie i kulturowo. Nadal jednak Europa - w tym także Polska - pozostaje terytorium, na którym obszary wiejskie stanowią wg różnych klasyfikacji od $80 \%$ 
do $95 \%$ powierzchni ${ }^{1}$. Również dynamika przemian obszarów wiejskich w Europie jest bardzo zróżnicowana i wielokierunkowa, co może prowadzić zarówno do ich zapaści, jak też i rozkwitu. Według Zawalińskiej ${ }^{2}$ zrównoważony rozwój może tu być traktowany jako skumulowany efekt takich zmiennych jak; uwarunkowania przyrodnicze, zatrudnienie, struktura demograficzna, stan infrastruktury gospodarczej, struktura sieci osadniczej, czy też stanów warunkowanych złożonymi procesami historycznymi i politycznymi.

Także sama instytucjonalna i naukowa delimitacja obszarów wiejskich oraz ich waloryzacja z czasem ulegała procesom przemian. Wiejskość i miejskość zostały wzbogacone o różnie definiowane strefy przejściowe, wzajemnie zazębiające się i upodabniające. Źródła dochodów ludności wiejskiej, pierwotnie niemal wyłącznie lub głównie oparte o pracę $\mathrm{w}$ rolnictwie ulegały głębokiej dywersyfikacji prowadząc z czasem do zmniejszenia się, a nawet do marginalizacji udziału dochodów z rolnictwa $\mathrm{w}$ dochodach wiejskich gospodarstw domowych ${ }^{3}$. Obecnie obszary wiejskie są różnorodnie definiowane przez poszczególne dyscypliny nauki, a także różnicowane $\mathrm{w}$ ramach tworzonego ładu instytucjonalnego przez europejskie organizacje współpracy gospodarczej i politycznej. Socjolodzy sprowadzają definicję wiejskości do rolnoleśnego wykorzystania ziemi, skupienia ludności w niewielkich jednostkach osadniczych o odrębnym stylu życia, wynikającym z zamieszkiwania w ekstensywnym krajobrazie i silniej identyfikacji ze środowiskiem przyrodniczym². Wieś i wiejskość wiązana jest zwykle ze specyficznymi funkcjami społecznymi, w tym kulturą lokalną (materialną $\mathrm{i}$ niematerialna), funkcjami przyrodniczymi i ich ochroną oraz wartościami kompensacyjnymi takimi jak spokój, cisza, czystość środowiska ${ }^{4}$. Ekonomiści, zwłaszcza zajmujący się problematyką rolniczą już od lat 70 . XX wieku wieś, czy obecnie obszary, wiejskie postrzegają jako przestrzeń wielofunkcyjną. Wielofunkcyjność obszarów wiejskich wiążą bezpośrednio z różnorodnymi dziedzinami gospodarki wkomponowanymi w wiejską przestrzeń, lokalną przedsiębiorczość, ale także z dywersyfikacją samego rolnictwa ${ }^{5}$.

Istnieje także wiele, choć już bardziej precyzyjnych delimitacji obszarów wiejskich ujmowanych instytucjonalnie, czy też formalno-prawnie. Według kryteriów administracyjnych, w Polsce wyróżnia się trzy rodzaje gmin: wiejskie, miejsko-wiejskie (posiadające na swym terytorium miasta) oraz miejskie. Według tej klasyfikacji obszary stricte wiejskie stanowią $64,2 \%$ powierzchni gmin w Polsce. Główny Urząd Statystyczny opiera podział terytorium kraju o wskaźnik gęstości zaludnienia przyjmując jako ograniczoną wartość tożsamą z kryteriami OECD dla wsi na poziomie poniżej 150 osób $/ \mathrm{km}^{2}$. Jest to kryterium wyższe niż przyjmowane przez EUROSTAT, w którym

\footnotetext{
1. Wilkin Ewolucja paradygmatów rozwoju obszarów wiejskich. Wieś i Rolnictwo 2008, (3) 140.

${ }^{2} \mathrm{~K}$. Zawalińska . Instrumenty $i$ efekty wsparcia Unii Europejskiej dla regionalnego rozwoju obszarów wiejskich $w$ Polsce. Seria: Problemy rozwoju wsi i rolnictwa. IRWIR PAN, Warszawa, 2009, s. 26-36.

3 W. Sroka, W. Musiał. Rolnictwo $i$ gospodarstwa rolne na obszarach miejskich $i$ podmiejskich. Konceptualizacja oraz przesłanki rozwoju Folia Pomerania, Oeconomica 2016, 329(84)3, 123-134.

4 A. Kaleta. Obszary wiejskie i koncentracje jego rozwoju. W: Rozwój obszarów wiejskich w perspektywie integracji z UE. FAPA, UMK, SGGW, Toruń 1998.

5 J. Kostrowicki. Obszary wiejskie jako przestrzeń wielofunkcyjna. Zagadnienia badawcze $i$ planistyczne. Przegląd Geograficzny 1976, z. XLVII z. 4
} 
graniczna gęstość zaludnienia wynosi 100 osób $/ \mathrm{km}^{2}{ }^{6}$. Dla celów polityki gospodarczej, zwłaszcza krajowej stosowane są także różnorodne typologie obszarów wiejskich, w których wieloaspektowo i w sposób złożony metodycznie analizowany i kwantyfikowany jest ich rozwój gospodarczy, kapitał ludzki, kapitał ekonomiczny, czy też uwarunkowania przyrodnicze, ważne zwłaszcza dla rolniczo-wiejskich aspektów analiz $^{7} 8$. Dijkstra i Poelmann 9 wychodząc od klasyfikacji regionów wprowadzonej przez OECD proponują rozszerzenie jej na pięć kategorii w zależności od czasu dostępu do najbliższego miasta. Autorzy rozważają zasadność przeklasyfikowania regionów odległych (typowo wiejskich) na pośrednie jeżeli czasu dojazdu się zmniejsza. Dijkstra i Ruiz $^{10}$ prowadzą rozważania nad wpływem czasu dojazdu do ośrodka miejskiego na zatrudnienie i demografię odległych regionów wiejskich.

Celem opracowania była ocena stanu i zakresu zróżnicowania oraz wielowymiarowości problemu i znaczenia obszarów wiejskich w poszczególnych krajach Unii Europejskiej. W opracowaniu dokonano oszacowania wpływu rozpatrywanych czynników na rozważane zagadnienie badawcze.

\section{Metodyka badań}

Oceny znaczenia obszarów wiejskich w poszczególnych krajach Unii Europejskiej dokonano w oparciu o dane statystyczne EUROSTAT. Zmienne dobrano stosownie do standardowej metodologii oceny polityk rolnych ${ }^{11}$. W opracowaniu do badań stanu rozwoju i dynamiki zmian na obszarach wiejskich przyjęto cztery wymiary ich oceny, tj. zmienne charakteryzujące:

- udział obszarów wiejskich w ogólnej powierzchni danego kraju,

- udział ludności zamieszkującej na obszarach wiejskich w całości struktury demograficznej kraju,

- odsetek zatrudnionych na obszarach wiejskich,

- udział obszarów wiejskich w wypracowaniu wartości dodanej brutto.

Zagadnienie badawcze rozpatrywano dla 2000 i 2015 roku. Niemniej, baza danych statystycznych nie zawierała dla niektórych krajów pełnych informacji liczbowych. W przypadku braków danych, dla celów porównań międzyokresowych opierano się odpowiednio na pierwszym i ostatnim z lat, dla których były dostępne informacje statystyczne.

\footnotetext{
${ }^{6}$ K. Zawalińska . Instrumenty $i$ efekty wsparcia Unii Europejskiej dla regionalnego rozwoju obszarów wiejskich $w$ Polsce. Seria: Problemy rozwoju wsi i rolnictwa. IRWIR PAN, Warszawa, 2009, s. 26-36.

${ }^{7}$ A. Rosner. Zmiany rozkładu przestrzennego zaludnienia obszarów wiejskich. Wiejskie obszary zmniejszajace zaludnienie $i$ koncentracje ludności wiejskiej. Seria: Problemy rozwoju wsi i rolnictwa. IRWIR PAN, Warszawa 2012, s. 53-64.

${ }^{8}$ M. Stanny. Poziom rozwoju obszarów wiejskich w Polsce - pomiar zjawiska złożonego. W: Rozwój wsi i rolnictwa w Polsce. Aspekty przestrzenne i regionalne red. Nauk A. Rosner. Seria: Problemy rozwoju wsi i rolnictwa. IRWIR PAN, Warszawa 2012, s. 93-100

${ }^{9}$ Dijkstra Lewis, Poelmann Hugo, Remote Rural Regions - How proximity to a city influences the performance of rural regions, DG Regio, European Commission, Brussels 2008

${ }^{10}$ Dijkstra Lewis, Ruiz Vicente. Refinement of the OECD regional typology: Economic Performance of Remote Rural Regions, DG Regio, European Commission, Brussels. 2010.

${ }^{11}$ Rural Development in the EU. Statistical and Economic Information Report 2013, European Commission, Brussels.
} 
Wzorce w zakresie podobieństw obszarów wiejskich wśród krajów UE wykrywano z wykorzystaniem grupowania odwołującego się do metody statystycznej określanej mianem analizy skupień. Segmentacji zbioru informacji statystycznej (dla czterech wskazanych powyżej zmiennych) dla ostatniego okresu badań dokonano z wykorzystaniem hierarchicznej analizy skupień. Podejście tego typu polega na sekwencyjnej próbie identyfikacji struktury skupień rozpatrywanych cech (zmiennych). Funkcją odległości między stanami cech obiektów była odległość euklidesowa. Aglomeracji obiektów dokonano w oparciu o algorytm Warda. Właściwością grupowania hierarchicznego jest brak jawnie zdefiniowanej globalnej funkcji oceny procesu. W to miejsce, celem wyodrębnienia par obiektów (analizowanych krajów) do łączenia lub rozdzielenia zbioru danych, szacowano lokalne oceny par skupień danego hierarchicznego grupowania. Stąd, różne lokalne funkcje oceny mogą skutkować odmiennymi efektami grupowania. Z jednej strony rozstrzygajacy głos badacza zapewniła elastyczność podejścia do wyróżniania podgrup analizowanego zbioru danych. Z drugiej strony, decyzje odnośnie kształtu delimitacji mogły prowadzić do znacznego zakresu arbitralności wyborów w odniesieniu do segmentacji danych. Niemniej, konieczność zachowania elastyczności ujęcia problemu badawczego wynika z braku jednoznacznych rekomendacji odnośnie charakteru finalnego grupowania. Proces poszukiwania wzorców w danych wykonano korzystając z analizy skupieńn ${ }^{12} 131415$.

Badanie z użyciem analizy taksonomicznej objęły dwa powiązane etapy. Pierwszym była segmentacja zbioru informacji statystycznej na możliwie jednorodne grupy. Następnie przeprowadzono statystyczną charakterystykę wyodrębnionych skupień i nadanie im stosownych opisów. Grupowanie obiektów (tj. krajów) nakierowane było na separację zbioru państw UE na podgrupy, aby ich elementy były do siebie podobne, a jednocześnie jak najbardziej odmienne od pozostałych podzbiorów. Profilowania podgrup zidentyfikowanych na etapie analizy skupień dokonano z wykorzystaniem techniki drzew klasyfikacyjnych i regresyjnych (C\&RT). Ta hierarchiczna procedura dyskryminacji zbioru danych znalazła odzwierciedlenie w graficznym diagramie $w$ formie drzewa decyzyjnego. Oceny wypływu cech wykorzystywanych do tworzenia skupień na zmienną zależną - kategorie skupień poszukiwano poprzez rekurencyjne podziały zbioru danych na podzbiory rozłączne metodą C\&RT, którymi także identyfikowano podstawę tych podziałów. Budowa modelu wyjaśniającego zależności $\mathrm{w}$ zbiorze danych $\mathrm{w}$ oparciu o metodę nieparametryczną (jaką jest metoda drzew klasyfikacyjnych) uwalniała od konieczności znajomości rozkładów cech oraz nie wymaga spełnienia często restrykcyjnych założeń formalnych w tym zakresie ${ }^{16}$.

W opracowaniu zastosowano podział obszarów wiejskich na trzy kategorie: obszary wiejskie), obszary pośrednie (tj. wiejsko-miejskie) oraz razem ujmowane obszary wiejskie i pośrednie. Dla celów delimitacji przyjęto dane faktualne opisu podstaw typologii obszarów wiejskich według EUROSTAT. Obszary wiejskie stanowiły

\footnotetext{
${ }^{12}$ D. Hand, H. Mannila, P. Smyth. Eksploracja danych. Wydawnictwa Naukowo-Techniczne, Warszawa 2005.

${ }^{13}$ J. Koronacki, J. Ćwik. Statystyczne systemy uczace się. Exit, Warszawa 2008.

${ }^{14}$ Larose D.L. Odkrywanie wiedzy z danych, wprowadzenie do eksploracji danych. Wydawnictwo Naukowe PWN, Warszawa 2007.

${ }^{15}$ T. Marek. Analiza skupień w badaniach empirycznych. Metody SAHN. PWN, Warszawa 1989.

${ }^{16}$ T. Marek. Analiza skupień w badaniach empirycznych. Metody SAHN. PWN, Warszawa 1989.
} 
subregiony wyodrębnione na poziomie NUTS 3, które nie spełniały warunków wyznaczonych dla obszarów miejskich. Delimitacji dokonuje się w oparciu tzw. „gridy” (kwadraty $1 \times 1 \mathrm{~km}$ wyznaczone przez linie siatki geograficznej). Dany „grid” jest kwalifikowany jako obszar miejski jeśli wypełnia oba poniższe warunki:

- gęstość zaludnienia na obszarze danego ,gridu” wynosi powyżej 300 osób/km2,

- minimalna liczba ludności na obszarze danego „gridu” wraz z ośmioma sąsiadującymi „gridami” wynosi powyżej 5 tys. osób.

Natomiast obszary pośrednie tj. wiejsko-miejskie wyodrębniane są w oparciu o kryteria 20-50\% udziału ludności zamieszkującej tereny wiejskie. Analizy statystyczne poprzedzono inwentaryzacyjną oceną stanu i rozwoju obszarów wiejskich krajów UE, dla których EUROSTAT zgromadził obszerne (choć niepełne) bazy danych.

\section{Analiza stanu obszarów wiejskich Unii Europejskiej}

Powierzchnia geograficzna Unii Europejskiej wynosi ogółem 4554,9 tys. km². W skład tego obszaru wchodzi 4369,4 tys. $\mathrm{km}^{2}$ terenów lądowych oraz 132,3 tys. $\mathrm{km}^{2}$ zajmowanych przez wody. Ogólna powierzchnia obszarów wiejskich i pośrednich wynosi w UE-28 3883,8 tys. $\mathrm{km}^{2}$ z czego na obszary wiejskie przypada 1928,7 tys. $\mathrm{km}^{2}$, tj. 49,7\%. Najwięcej w ujęciu bezwzględnym obszarów wiejskich jest we Francji i w Szwecji odpowiednio 582,4 tys. km² i 381,2 tys. km². 


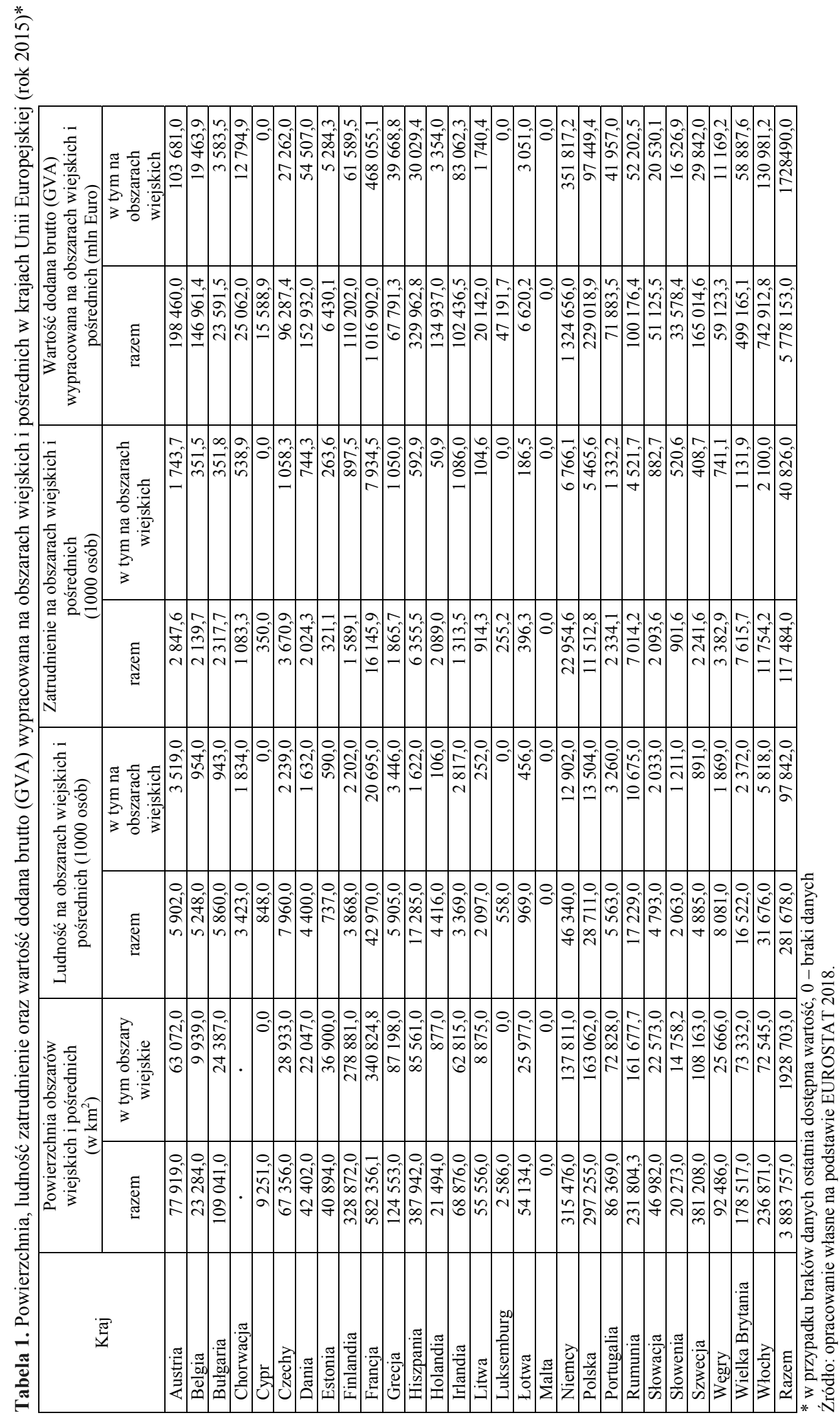


Z kolei w Holandii obszary wiejskie i pośrednie stanowią tylko 21,49 tys. ha, w tym wiejskie 0,88 tys. $\mathrm{km}^{2}$, a w Luksemburgu obszary pośrednie i wiejskie zajmujące 2,59 tys. ha i nie podlegają dalszemu podziałowi, co oznacza, że w kraju tym nie wyodrębnia się terenów sklasyfikowanych jako typowo wiejskie (tab. 1). Statystykę tą uzupełnia analiza udziału obszarów ocenianych w trzech kategoriach tj. obszarów wiejskich, pośrednich oraz wiejskich i pośrednich ujmowanych łącznie (tab. 2). Największy udział obszarów stricte wiejskich w krajach UE posiada Irlandia - 90,0 \% oraz Finlandia i Estonia, odpowiednio 82,4\% i 81,6\%. Polska w tej klasyfikacji lokuje się niemal w środku zestawienia europejskiego przy udziale obszarów wiejskich na poziomie $52,1 \%$. Natomiast w Holandii jest to tylko 2,1\%, na Litwie 13,6\%, a w Hiszpanii 16,9\%.

Tabela 2. Udział obszarów wiejskich i pośrednich w wybranych krajach UE w latach 2000 i 2015

\begin{tabular}{|c|c|c|c|c|c|c|}
\hline \multirow[t]{2}{*}{ Kraje } & \multicolumn{2}{|c|}{$\begin{array}{l}\text { Udział obszarów } \\
\text { wiejskich }\end{array}$} & \multicolumn{2}{|c|}{$\begin{array}{c}\text { Udział obszarów } \\
\text { pośrednich (wiejsko- } \\
\text { miejskie) }\end{array}$} & \multicolumn{2}{|c|}{$\begin{array}{c}\text { Razem udział obszarów wiejskich } \\
\text { i pośrednich }\end{array}$} \\
\hline & $2000 \mathrm{r}$. & 2015 r. & $2000 \mathrm{r}$. & $2015 \mathrm{r}$. & $2000 \mathrm{r}$. & 2015 r. \\
\hline Austria & 75,2 & 75,2 & 17,7 & 17,7 & 92,9 & 92,9 \\
\hline Belgia & 32,6 & 32,6 & 43,7 & 43,7 & 76,3 & 76,3 \\
\hline Bułgaria & 22,1 & 22,1 & 76,7 & 76,7 & 98,8 & 98,8 \\
\hline Chorwacja & $\cdot$ & $\cdot$ & $\cdot$ & $\cdot$ & $\cdot$ & $\cdot$ \\
\hline Cypr & $\cdot$ & $\cdot$ & 100,0 & 100,0 & 100,0 & 100,0 \\
\hline Czechy & 36,8 & 36,7 & 48,6 & 48,7 & 85,4 & 85,4 \\
\hline Dania & 51,5 & 51,4 & 47,3 & 47,4 & 98,8 & 98,8 \\
\hline Estonia & 82,4 & 81,6 & 7,7 & 8,8 & 90,1 & 90,4 \\
\hline Finlandia & 82,4 & 82,4 & 14,7 & 14,8 & 97,2 & 97,2 \\
\hline Francja & 53,9 & 53,9 & 38,2 & 38,2 & 92,1 & 92,1 \\
\hline Grecja & 66,1 & 66,0 & 28,3 & 28,3 & 94,3 & 94,3 \\
\hline Hiszpania & 16,9 & 16,9 & 59,8 & 59,8 & 76,7 & 76,7 \\
\hline Holandia & 4,1 & 2,0 & 49,0 & 49,6 & 51,0 & 51,7 \\
\hline Irlandia & 90,0 & 90,0 & 8,7 & 8,7 & 98,7 & 98,7 \\
\hline Litwa & 12,8 & 13,6 & 72,5 & 71,5 & 85,2 & 85,1 \\
\hline Luksemburg & $\cdot$ & $\cdot$ & 100,0 & 100,0 & 100,0 & 100,0 \\
\hline Lotwa & 40,4 & 40,2 & 43,6 & 43,6 & 84,0 & 83,8 \\
\hline Malta & $\cdot$ & $\cdot$ & $\cdot$ & $\cdot$ & $\cdot$ & $\cdot$ \\
\hline Niemcy & 38,6 & 38,6 & 49,7 & 49,7 & 88,3 & 88,3 \\
\hline Polska & 52,1 & 52,1 & 42,9 & 42,9 & 95,0 & 95,0 \\
\hline Portugalia & 79,0 & 79,0 & 14,7 & 14,7 & 93,7 & 93,7 \\
\hline Rumunia & 67,8 & 67,8 & 29,4 & 29,4 & 97,2 & 97,2 \\
\hline Słowacja & 46,1 & 46,0 & 49,7 & 49,8 & 95,8 & 95,8 \\
\hline Słowenia & 72,8 & 72,8 & 27,2 & 27,2 & 100,0 & 100,0 \\
\hline Szwecja & 24,7 & 24,7 & 62,3 & 62,3 & 87,0 & 87,0 \\
\hline Węgry & 27,6 & 27,6 & 71,9 & 71,8 & 99,5 & 99,4 \\
\hline Wielka Brytania & 29,5 & 29,5 & 42,3 & 42,3 & 71,8 & 71,8 \\
\hline Włochy & 24,0 & 24,0 & 54,4 & 54,4 & 78,4 & 78,4 \\
\hline Średnia & 47,0 & 46,9 & 46,2 & 46,2 & 93,2 & 93,1 \\
\hline
\end{tabular}

Źródło: opracowanie własne na podstawie EUROSTAT 2018.

W wielu krajach UE obszary pośrednie tj. wiejsko-miejskie dominują obszarowo, a stąd i udziałem mierzonym w odsetkach nad obszarami wiejskimi. Dotyczy to zwłaszcza kilku krajów, które w późniejszym okresie uzyskały członkostwo w UE tj. w Bułgarii jest 76,6\% obszarów wiejsko - miejskich i kolejno na Litwie 71,5\%, na Węgrzech 
$71,8 \%$ i na Słowacji 49,8\%. Tylko w niektórych „starych” krajach UE proporcje te są podobne, tj. obszary wiejsko-miejskie dominują nad wiejskimi. W Hiszpanii proporcje te wynoszą $59,8 \%$ do $16,9 \%$, w Niemczech $49,7 \%$ do $38,6 \%$ a Szwecji $62,3 \%$ do $24,7 \%$. Po skumulowaniu udziału obszarów wiejskich i wiejsko-miejskich uwidacznia się ich dominacja we wszystkich krajach UE. W większości krajów udział tych skumulowanych typów obszarowych wynosi ponad 90\%, przy średniej dla UE 93,1\%. W statystykach Słowenii i Luksemburgu jest to $100 \%$, na Węgrzech 99,4\%, w Rumunii 97,2\%. Niejako na drugim biegunie tych porównań są Holandia $(51,7 \%)$ oraz Wielka Brytania i Belgia odpowiednio $71,8 \%$ i $76,3 \%$. W rozważanych 15 latach, w instytucjonalnie ocenianych zmianach w powierzchni i udziale obszarów wiejskich nie zaszły większe zmiany. Jedynie w Holandii udział obszarów wiejskich zmniejszył się z 4,1\% do 2,0\%, a w Estonii wzrósł udział obszarów pośrednich z 7,7\% do 8,8\%.

Tabela 3. Udział ludności na obszarach wiejskich i pośrednich w wybranych krajach UE w latach 2000 i 2015

\begin{tabular}{|c|c|c|c|c|c|c|}
\hline \multirow[t]{2}{*}{ Kraje } & \multicolumn{2}{|c|}{$\begin{array}{l}\text { Ludność na } \\
\text { obszarach wiejskich }\end{array}$} & \multicolumn{2}{|c|}{$\begin{array}{c}\text { Ludność na obszarach } \\
\text { pośrednich (wiejsko-miejskie) }\end{array}$} & \multicolumn{2}{|c|}{$\begin{array}{c}\text { Razem ludność na } \\
\text { obszarach wiejskie i } \\
\text { pośrednich }\end{array}$} \\
\hline & $2000 \mathrm{r}$. & 2015 r. & $2000 \mathrm{r}$. & 2015 r. & $2000 \mathrm{r}$. & $2015 \mathrm{r}$. \\
\hline Austria & 43,1 & 40,8 & 27,6 & 27,6 & 70,7 & 68,4 \\
\hline Belgia & 8,5 & 8,5 & 38,7 & 38,2 & 47,2 & 46,7 \\
\hline Bułgaria & 14,7 & 13,1 & 70,4 & 68,5 & 85,1 & 81,6 \\
\hline Chorwacja & 43,7 & 43,6 & 37,9 & 37,8 & 81,6 & 81,4 \\
\hline Cypr & $\cdot$ & $\cdot$ & 100,0 & 100,0 & 100,0 & 100,0 \\
\hline Czechy & 21,5 & 21,2 & 56,2 & 54,3 & 77,7 & 75,5 \\
\hline Dania & 30,1 & 28,7 & 48,5 & 48,7 & 78,6 & 77,4 \\
\hline Estonia & 48,6 & 45,0 & 13,1 & 11,2 & 61,7 & 56,2 \\
\hline Finlandia & 42,6 & 40,2 & 30,6 & 30,4 & 73,2 & 70,6 \\
\hline Francja & 31,6 & 31,2 & 33,6 & 33,6 & 65,2 & 64,8 \\
\hline Grecja & 32,1 & 31,8 & 22,0 & 22,7 & 54,1 & 54,5 \\
\hline Hiszpania & 4,0 & 3,5 & 34,3 & 33,7 & 38,3 & 37,2 \\
\hline Holandia & 0,7 & 0,6 & 26,1 & 25,4 & 26,8 & 26,0 \\
\hline Irlandia & 60,8 & 60,7 & 10,3 & 11,9 & 71,1 & 72,6 \\
\hline Litwa & 9,3 & 8,7 & 66,4 & 63,6 & 75,7 & 72,3 \\
\hline Luksemburg & $\cdot$ & $\cdot$ & 100,0 & 100,0 & 100,0 & 100,0 \\
\hline Lotwa & 23,1 & 23,1 & 29,7 & 26,0 & 52,8 & 49,1 \\
\hline Malta & $\cdot$ & $\cdot$ & $\cdot$ & $\cdot$ & $\cdot$ & $\cdot$ \\
\hline Niemcy & 16,7 & 15,8 & 41,4 & 40,9 & 58,1 & 56,7 \\
\hline Polska & 35,4 & 35,1 & 38,4 & 39,5 & 73,8 & 74,6 \\
\hline Portugalia & 33,6 & 31,5 & 21,7 & 22,2 & 55,3 & 53,7 \\
\hline Rumunia & 55,5 & 53,9 & 32,6 & 33,1 & 88,1 & 87,0 \\
\hline Słowacja & 37,0 & 37,5 & 51,5 & 50,9 & 88,6 & 88,4 \\
\hline Słowenia & 61,0 & 58,7 & 39,0 & 41,3 & 100,0 & 100,0 \\
\hline Szwecja & 9,9 & 9,1 & 42,0 & 40,8 & 51,9 & 49,9 \\
\hline Węgry & 19,9 & 19,0 & 62,7 & 63,1 & 82,6 & 82,1 \\
\hline Wielka Brytania & 3,7 & 3,6 & 21,7 & 21,7 & 25,4 & 25,4 \\
\hline Włochy & 10,0 & 9,6 & 42,4 & 42,6 & 52,4 & 52,2 \\
\hline Średnia & 27,9 & 27,0 & 42,2 & 41,8 & 70,1 & 68,8 \\
\hline
\end{tabular}

Źródło: opracowanie własne na podstawie EUROSTAT 2018. 
Na obszarze UE w 2015 r., zamieszkiwało ogółem 508,54 mln ludności przy czym na obszarach wiejskich i pośrednich $281,68 \mathrm{mln}$, a stricte wiejskich 97,84 mln. Rozkład udziału ludności na tych obszarach jest wysoce zdywersyfikowany. Najwięcej ludności zamieszkuje na obszarach wiejskich we Francji 20,7 mln osób oraz w Polsce i w Niemczech, odpowiednio 13,5 i 12,9 mln osób. Jednak największy udział ludności zamieszkującej obszary wiejskie wykazuje Irlandia $(60,7 \%)$ oraz Rumunia $(53,9 \%)$. Z kolei najniższy udział tej kategorii analitycznej odnotowano w Holandii $(0,6 \%)$, Hiszpanii (3,5\%) i Wielkiej Brytanii (3,6\%). Analizując sumarycznie te dwie kategorie ludności w aspekcie miejsca zamieszkania poza Słowenią, Cyprem i Luksemburgiem (100\% ludności zamieszkuje obszary wiejskie i pośrednie), największy udział tych dwóch grup odnotowano na Słowacji $(88,4 \%)$ i w Rumunii $(87,0 \%)$ a najniższy w Wielkiej Brytanii $(25,4 \%)$ i Holandii $(26,0 \%)$. W ostatnim 15-leciu odnotowano także niewielkie zmiany w udziale ludności zamieszkującej obszary wiejskie. Jedynie w Słowacji nieznaczny przyrost ludności zamieszkującej obszary wiejskie z 37\% do 37,5\%. Natomiast nie odnotowano zmian w Belgii, na Łotwie, a w pozostałych krajach nieznaczne zmniejszania udziału ludności zamieszkującej na obszarach wiejskich. Relatywnie największe takie zmiany odnotowano w Estonii (spadek o 3,6 p.p.), w Austrii (spadek o 2,3 p.p.), Portugalii i Słowenii spadek odpowiednio o 2,1 p.p. i 2,3 p.p. Dane charakteryzujące zmiany udziału ludności zamieszkującej ujmowane łącznie tereny wiejskie i pośrednie wskazują na rozbieżność zachodzących przemian pomiędzy poszczególnymi krajami. Tak ujmowana „wiejskość” wzrosła, choć nieznacznie, w krajach jak: Hiszpania, Irlandia, Polska i Portugalia. W pozostałych krajach uległa nieznaczącym obniżeniu (1,0-2,0 p.p.).

W roku 2015 w UE-28 zatrudnienie wyniosło ogółem 215804,2 tys. osób, a na obszarach wiejskich i pośrednich łącznie aktywnych ekonomicznie osób było ok. 117484 tys., tj. 54,4\% ogółu zatrudnionych, w tym 26,7\% wyłącznie na obszarach wiejskich. Największy udział zatrudnionych na obszarach wiejskich (tab. 4) odnotowano w Słowenii (57,7\%), Irlandii (57,2\%) i Rumunii (54,9\%).

Tabela 4. Udział zatrudnionych na obszarach wiejskich i pośrednich w krajach UE w latach $2000 \mathrm{i}$ 2015

\begin{tabular}{|c|c|c|c|c|c|c|}
\hline \multirow[t]{2}{*}{ Kraje } & \multicolumn{2}{|c|}{$\begin{array}{l}\text { Zatrudnionych na } \\
\text { obszarach wiejskich }\end{array}$} & \multicolumn{2}{|c|}{$\begin{array}{c}\text { Zatrudnionych na } \\
\text { obszarach pośrednich } \\
\text { (wiejsko-miejskie) }\end{array}$} & \multicolumn{2}{|c|}{$\begin{array}{c}\text { Razem zatrudnionych na } \\
\text { obszarach wiejskich i } \\
\text { pośrednich }\end{array}$} \\
\hline & $2000 \mathrm{r}$ & $2015 \mathrm{r}$ & $2000 \mathrm{r}$. & $2015 \mathrm{r}$. & $2000 \mathrm{r}$ & 2015 r. \\
\hline Austria & 42,5 & 42,9 & 26,8 & 27,1 & 69,3 & 70,0 \\
\hline Belgia & 7,1 & 7,8 & 37,3 & 39,7 & 44,4 & 47,5 \\
\hline Bułgaria & 10,2 & 11,8 & 28,8 & 66,1 & 39,0 & 77,9 \\
\hline Chorwacja & 34,5 & 34,6 & 35,1 & 34,9 & 69,6 & 69,5 \\
\hline Cypr & $\cdot$ & $\cdot$ & 100,0 & 100,0 & 100,0 & 100,0 \\
\hline Czechy & 20,1 & 21,4 & 51,5 & 52,9 & 71,6 & 74,4 \\
\hline Dania & 29 & 27,8 & 48,7 & 47,8 & 77,7 & 75,6 \\
\hline Estonia & 44,6 & 43 & 12,4 & 9,4 & 57,0 & 52,4 \\
\hline Finlandia & 28,3 & 37,9 & 15 & 29,2 & 43,3 & 67,1 \\
\hline Francja & 31,2 & 31,7 & 31,3 & 32,8 & 62,5 & 64,5 \\
\hline Grecja & 48,2 & 29,6 & 35,7 & 23,0 & 83,9 & 52,6 \\
\hline Hiszpania & 4,1 & 3,3 & 34,3 & 32,5 & 38,4 & 35,8 \\
\hline Holandia & 0,6 & 0,6 & 25,5 & 25,1 & 26,1 & 25,7 \\
\hline Irlandia & 57,3 & 57,2 & 10,7 & 12,0 & 68,0 & 69,2 \\
\hline
\end{tabular}




\begin{tabular}{|c|c|c|c|c|c|c|}
\hline \multirow[t]{2}{*}{ Kraje } & \multicolumn{2}{|c|}{$\begin{array}{l}\text { Zatrudnionych na } \\
\text { obszarach wiejskich }\end{array}$} & \multicolumn{2}{|c|}{$\begin{array}{l}\text { Zatrudnionych na } \\
\text { obszarach pośrednich } \\
\text { (wiejsko-miejskie) }\end{array}$} & \multicolumn{2}{|c|}{$\begin{array}{l}\text { Razem zatrudnionych na } \\
\text { obszarach wiejskich i } \\
\text { pośrednich }\end{array}$} \\
\hline & $2000 \mathrm{r}$. & 2015 r. & $2000 \mathrm{r}$. & $2015 \mathrm{r}$ & $2000 \mathrm{r}$. & $2015 \mathrm{r}$. \\
\hline Litwa & 9,1 & 8,0 & 65,0 & 62,3 & 74,1 & 70,3 \\
\hline Luksemburg & $\cdot$ & $\cdot$ & 100,0 & 100,0 & 100,0 & 100,0 \\
\hline Lotwa & 22,8 & 21,5 & 26,2 & 24,2 & 49,0 & 45,7 \\
\hline Malta & $\cdot$ & $\cdot$ & $\cdot$ & $\cdot$ & $\cdot$ & $\cdot$ \\
\hline Niemcy & 15,3 & 17,3 & 38,3 & 41,3 & 53,6 & 58,6 \\
\hline Polska & 27,7 & 34,6 & 37,9 & 38,2 & 65,6 & 72,8 \\
\hline Portugalia & 44,6 & 30,9 & 26,8 & 23,3 & 71,4 & 54,2 \\
\hline Rumunia & 57,1 & 54,9 & 31,5 & 30,3 & 88,6 & 85,2 \\
\hline Słowacja & 35,6 & 36,7 & 49,6 & 50,3 & 85,2 & 87,0 \\
\hline Słowenia & 58,7 & 57,7 & 41,3 & 42,3 & 100 & 100,0 \\
\hline Szwecja & 9,5 & 8,8 & 40,1 & 39,3 & 49,6 & 48,1 \\
\hline Węgry & 18,2 & 17,7 & 62,3 & 63,3 & 80,5 & 81,0 \\
\hline Wielka Brytania & 4,1 & 4,4 & 27,4 & 25,1 & 31,5 & 29,5 \\
\hline Włochy & 13,1 & 9,6 & 34,2 & 43,9 & 47,3 & 53,5 \\
\hline Średnia & 26,9 & 26,1 & 39,8 & 41,3 & 66,7 & 67,4 \\
\hline
\end{tabular}

Źródło: opracowanie własne na podstawie EUROSTAT 2018.

$\mathrm{Na}$ drugim biegunie zatrudnienia na obszarach wiejskich jest Holandia $(0,6 \%)$, Hiszpania (3,3\%) i Wielka Brytania (4,4\%). W Polsce udział ten wynosi 34,6\% i jest taki sam, jak w Chorwacji i zbliżony do krajów jak Słowacja $(36,7 \%)$ i Finlandia $(37,9 \%)$. $\mathrm{Na}$ obszarach pośrednich (wiejsko-miejskich) większy udział zatrudnionych niż na obszarach wiejskich odnotowano w takich krajach jak Bułgaria (różnica 54,3\%), Litwa (różnice także 54,3\%) oraz w Słowenii i na Węgrzech, różnice odpowiednio 30,5\% i 45,6\% Ogółem zatrudnienie na obszarach wiejskich i pośrednich wynosi, w analizowanych krajach UE 67,4\%, poza Cyprem, Słowenią i Luksemburgiem (po $100 \%$ ), a najwyższe odnotowano na Słowacji $(87,0 \%)$, w Rumunii $(85,2 \%)$ i na Węgrzech $(81,0 \%)$, a najniższe w Holandii $(25,7 \%)$ oraz w Wielkiej Brytanii $(29,5 \%)$. $\mathrm{W}$ analizowanym okresie 15 lat obszary wiejskie i pośrednie ujmowane łącznie zmniejszyły swój potencjał w tym zakresie odpowiednio o 0,8 p.p., a na obszarach wiejskich i obszarach pośrednich zwiększyły o 1,5 p.p. Najwyższe spadki zatrudnienia na obszarach wiejskich odnotowano w Grecji o 18,6 p.p. Portugalii o 13,7 p.p. i we Włoszech 3,5 p.p. Najsilniej natomiast wzrosło zatrudnienie w Finlandii i w Polsce, odpowiednio o 9,6 p.p. i 6,9 p.p.

Ogólny potencjał gospodarczy analizowanych krajów UE oceniany poprzez wielkość i udział wartości dodanej brutto (GVA) wzrósł w latach 2000 - 2015 o 53,2\%, tj. do poziomu 13261,8 mld $€$. Na obszarach wiejskich udział ten wyniósł w $2015 \mathrm{r}$. ogółem 1728,5 mld $€$, tj. 12,3\%, a łącznie na analizowanych obszarach wiejskich i mieszanych 5778,1 mld €, tj. 43,6\% ogólnego poziomu GVA. Najwyższa wartość dodana brutto wypracowywana jest na obszarach wiejskich we Francji $(468,0 \mathrm{mln} €$ ) oraz w Niemczech $(351,8$ mld $€$ ), co wynika między innymi z wielkości i ogólnie dużego potencjału gospodarczego zlokalizowanego na obszarach wiejskich tych krajów. W Polsce GVA wypracowywana na obszarach wiejskich wynosi ok 97,5 mld $€$ i jest porównywalna z Austrią (103,4 mld $€$ ) i znacznie wyższa aniżeli w Wielkiej Brytanii $(58,9$ mld $€)$. Jednak najwyższy udział GVA jest wypracowywany na obszarach wiejskich Słowenii 49,2\% oraz Irlandii (46,5\%) (tab. 5). 
Tabela 5. Udział wartości dodanej brutto (GVA) wypracowanej na obszarach wiejskich w krajach UE w latach 2000 i 2015

\begin{tabular}{|c|c|c|c|c|c|c|}
\hline \multirow[t]{2}{*}{ Kraje } & \multicolumn{2}{|c|}{$\begin{array}{l}\text { Udział GVA na } \\
\text { obszarach wiejskich }\end{array}$} & \multicolumn{2}{|c|}{$\begin{array}{c}\text { Udział GVA na obszarach } \\
\text { pośrednich (wiejsko-miejskie) }\end{array}$} & \multicolumn{2}{|c|}{$\begin{array}{c}\text { Razem Udział GVA } \\
\text { na obszarach wiejskich } \\
\text { i pośrednich }\end{array}$} \\
\hline & 2000 r. & 2015 r. & 2000 r. & 2015 r. & $2000 \mathrm{r}$. & $2015 \mathrm{r}$. \\
\hline Austria & 32,4 & 33,8 & 31,2 & 30,9 & 63,6 & 64,7 \\
\hline Belgia & 5,4 & 5,3 & 33,7 & 34,7 & 39,1 & 40,0 \\
\hline Bułgaria & 11,1 & 9,2 & 63,3 & 51,1 & 74,4 & 60,3 \\
\hline Chorwacja & 37,3 & 34,0 & 33,3 & 32,6 & 70,6 & 66,6 \\
\hline Cypr & - & - & 100,0 & 100,0 & 100,0 & 100,0 \\
\hline Czechy & 19,1 & 18,0 & 47,3 & 45,5 & 66,4 & 63,5 \\
\hline Dania & 26,0 & 23,5 & 43,7 & 42,4 & 69,7 & 65,9 \\
\hline Estonia & 34,5 & 30,0 & 8,4 & 6,5 & 42,9 & 36,5 \\
\hline Finlandia & 34,4 & 34,1 & 28,6 & 26,9 & 63,0 & 61,0 \\
\hline Francja & 25,7 & 23,9 & 29,6 & 28,0 & 55,3 & 51,9 \\
\hline Grecja & 26,8 & 25,5 & 18,8 & 18,1 & 45,6 & 43,6 \\
\hline Hiszpania & 3,3 & 3,1 & 31,0 & 30,6 & 34,3 & 33,7 \\
\hline Holandia & 0,6 & 0,5 & 22,0 & 21,5 & 22,6 & 22,0 \\
\hline Irlandia & 50,3 & 45,3 & 8,7 & 10,6 & 59,0 & 55,9 \\
\hline Litwa & 5,7 & 5,2 & 58,3 & 54,6 & 64,0 & 59,8 \\
\hline Luksemburg & . & $\cdot$ & 100,0 & 100,0 & 100,0 & 100,0 \\
\hline Łotwa & 14,4 & 14,3 & 19,9 & 16,7 & 34,3 & 31,0 \\
\hline Malta & $\cdot$ & $\cdot$ & $\cdot$ & $\cdot$ & $\cdot$ & $\cdot$ \\
\hline Niemcy & 12,6 & 12,9 & 35,3 & 35,6 & 47,9 & 48,5 \\
\hline Polska & 26,1 & 25,5 & 34,0 & 34,5 & 60,1 & 60,0 \\
\hline Portugalia & 27,1 & 26,8 & 17,5 & 19,1 & 44,6 & 45,9 \\
\hline Rumunia & 43,0 & 37,1 & 33,3 & 34,1 & 76,3 & 71,2 \\
\hline Słowacja & 29,8 & 28,8 & 45,4 & 43,0 & 75,2 & 71,8 \\
\hline Słowenia & 52,3 & 49,2 & 47,7 & 50,8 & 100,0 & 100,0 \\
\hline Szwecja & 8,4 & 7,5 & 36,5 & 34,0 & 44,9 & 41,5 \\
\hline Węgry & 13,6 & 12,0 & 51,5 & 51,6 & 65,1 & 63,6 \\
\hline Wielka Brytania & 2,7 & 2,6 & 19,7 & 19,2 & 22,4 & 21,8 \\
\hline Włochy & 8,9 & 8,8 & 41,7 & 41,2 & 50,6 & 50,1 \\
\hline Średnia & 22,1 & 20,7 & 38,5 & 37,5 & 60,6 & 58,2 \\
\hline
\end{tabular}

Źródło: opracowanie własne na podstawie EUROSTAT 2018.

Około jednej trzeciej GVA tworzone jest na obszarach wiejskich takich krajów jak Austria (33,8\%), Chorwacja (34,0\%), Estonia (30,0\%), Finlandia (34,1\%) i Rumunia $(37,1 \%)$. Polska $\mathrm{z}$ udziałem $25,5 \%$ jest podobna pod tym względem do Portugalii $(26,8 \%)$, Grecji $(25,5 \%)$ oraz Francji $(23,9 \%)$ i Finlandii $(34,1 \%)$. Średni udział GVA wytwarzanego na obszarach wiejskich ogółem w krajach UE w roku 2015 jest o 18,2 p.p. niższy niż na obszarach pośrednich. Zdecydowanie wyższy udział GVA wypracowywany jest na obszarach pośrednich w Belgii (o 29,4 p.p.), Bułgarii (o 41,9 p.p.) oraz Niemczech (o 22,7 p.p.), ale także na Węgrzech (o 39,6 p.p.). W Polsce różnice $\mathrm{w}$ tym zakresie nie są tak wielkie i wynoszą tylko około 9 p.p. Wyższe GVA wypracowywane jest na obszarach wiejskich aniżeli pośrednich w takich krajach jak Finlandia (o 7,2 p.p.), Grecja (o 7,4 p.p.) oraz Portugalia (o 7,7 p.p.). 


\section{Analiza statystyczna obszarów wiejskich}

Hierarchiczna metoda grupowania pozwoliła na przedstawienie w formie graficznej sekwencji procesu łączenia (bądź dzielenia) podgrup. Jej wyniki zaprezentowano $\mathrm{w}$ formie dendrogramu. Finalne skupienia otrzymano przez obcięcie dendrogramu na wybranym poziomie. Dla Chorwacji, Cypru, Luksemburga i Malty braki danych odnośnie udziału obszarów wiejskich skutkowały wykluczeniem tych obiektów z analizy taksonomicznej. Na kolejnych wynikach segmentacji państwa z brakami danych są prezentowane z przynależnością do grupy „zero" (oznaczanej symbolem”0”). Grupowanie przeprowadzone dla danych reprezentujących obszary wiejskie w UE odzwierciedla rysunek 1. Analizę skupień przeprowadzono w oparciu o osiem zmiennych - cztery charakterystyki podstawowe: udział powierzchni obszarów wiejskich, odsetek ludności na obszarach wiejskich, odsetek zatrudnionych na obszarach wiejskich, udział obszarów wiejskich w tworzeniu wartości dodanej brutto danego kraju. Do badania włączono także indeksy zmian dla wskazanych zmiennych pomiędzy pierwszym i ostatnim okresem analizy.

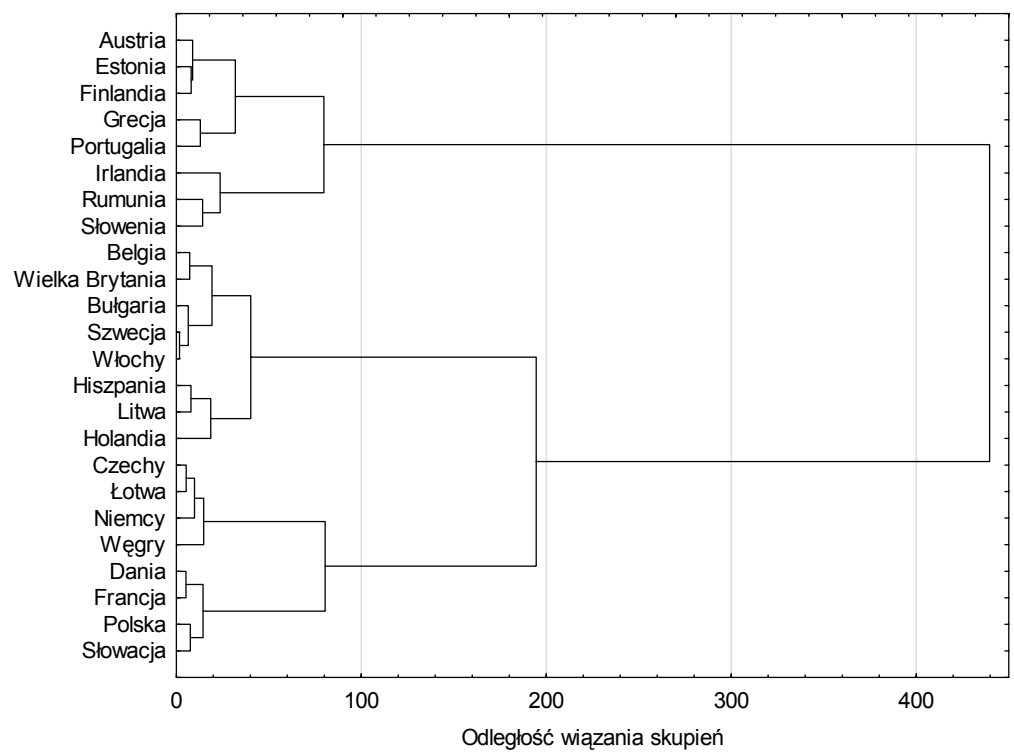

Rysunek 1. Grupowanie krajów UE ze względu na cechy opisujące ważność obszarów wiejskich (analiza skupień, metoda hierarchiczna)

Źródło: opracowanie własne na podstawie EUROSTAT 2018.

Separacja dendrogramu przeprowadzona na odległości 100 wiązań skutkuje wydzieleniem trzech grup państw. Każde ze skupień wyróżnionych metodą taksonomiczną składa się z ośmiu obiektów. W skład grupy pierwszej weszły: Belgia, Bułgaria, Hiszpania, Holandia, Litwa, Szwecja, Wielka Brytania oraz Włochy. Grupę drugą utworzyły Austria, Estonia, Finlandia, Grecja, Irlandia, Portugalia, Rumunia i Słowenia. Skupienie trzecie zostało uformowane w oparciu o Czechy, Danię, Francję, Łotwę, Niemcy, Polskę, Słowację oraz Węgry. W tabeli 6 zamieszczono najważniejsze 
charakterystyki różnicujące zidentyfikowane grupy państw ze względu na rolę obszarów wiejskich. W tabeli tej przedstawiono również odpowiednie statystyki dla grupy oznaczonej numerem zero, której wydzielenie nie wynika $\mathrm{z}$ grupowania procedurą taksonomiczna, ale jest pokłosiem braków danych dla niektórych z rozpatrywanych zmiennych.

Najważniejszym czynnikiem zróżnicowania dla obszarów wiejskich UE zdaje się być udział powierzchni tej kategorii w ogóle terytorium kraju. 76,85\% odsetkiem obszarów wiejskich charakteryzuje się skupienie drugie. Warunkuje to pośrednio wysokie udziały pozostałych z rozważanych wyróżników - w szczególności odsetka ludności zamieszkującej na obszarach wiejskich oraz udziału zatrudnionych na obszarach wiejskich. W grupie drugiej stosunkowo niższy jest natomiast udział wartości dodanej brutto wytwarzanej na obszarach wiejskich $(35,36 \%)$. Skupienie to mimo najwyższych wartości każdej ze zmiennych cechuje się ich najniższym zróżnicowaniem względnym (mierzonym współczynnikiem zmienności). Nieznacznie większą dyspersję rozważanych cech obserwowano $\mathrm{w}$ grupie trzeciej. Natomiast najwyższe zróżnicowanie (porównywalne ze średnim dla całości zbioru) każdej ze zmiennych opisujących ważność obszarów wiejskich odnotowano z grupie pierwszej. Kontrastowo do skupienia o najwyższych wartościach, w grupie pierwszej występują najniższe wartości poszczególnych cech. Dodatkowo, mimo średniego 20,68\% udziału obszarów wiejskich średnie wartości pozostałych trzech wskaźników oscylują jedynie w granicach 5-7\%. Grupa trzecia wykazuje analogie pod względem struktury wskaźników do skupienia drugiego, jednak wartości cech są w niej niższe minimum o jedną trzecią.

Tabela 6. Charakterystyka grup wyróżnionych metodą analizy skupień dla obszarów wiejskich

\begin{tabular}{|c|c|c|c|c|c|c|}
\hline \multirow{2}{*}{\multicolumn{2}{|c|}{ Oceniane zmienne }} & \multicolumn{5}{|c|}{ Grupy wyróżnione dla obszarów wiejskich } \\
\hline & & 0 & 1 & 2 & 3 & Ogółem \\
\hline \multirow{6}{*}{$\begin{array}{l}\text { Odsetek } \\
\text { powierzchni } \\
\text { obszarów } \\
\text { wiejskich (\%) }\end{array}$} & $\mathrm{N}$ & $\cdot$ & 8 & 8 & 8 & 24 \\
\hline & Średnia & $\cdot$ & 20,68 & 76,85 & 43,31 & 46,95 \\
\hline & Współczynnik zmienności & $\cdot$ & $46,9 \%$ & $10,4 \%$ & $21,1 \%$ & $53,4 \%$ \\
\hline & Rozstęp & $\cdot$ & 30,44 & 23,96 & 26,29 & 87,89 \\
\hline & Minimum & $\cdot$ & 2,11 & 66,03 & 27,59 & 2,11 \\
\hline & Maksimum & $\cdot$ & 32,55 & 90,00 & 53,89 & 90,00 \\
\hline \multirow{6}{*}{$\begin{array}{l}\text { Odsetek ludności } \\
\text { na obszarach } \\
\text { wiejskich (\%) }\end{array}$} & $\mathrm{N}$ & 1 & 8 & 8 & 8 & 25 \\
\hline & Średnia & 43,65 & 7,09 & 45,31 & 26,45 & 26,98 \\
\hline & Współczynnik zmienności & & $57,8 \%$ & $25,1 \%$ & $29,7 \%$ & $65,9 \%$ \\
\hline & Rozstęp & 0,00 & 12,51 & 29,21 & 21,70 & 60,06 \\
\hline & Minimum & 43,65 & 0,63 & 31,47 & 15,79 & 0,63 \\
\hline & Maksimum & 43,65 & 13,14 & 60,69 & 37,50 & 60,69 \\
\hline \multirow{6}{*}{$\begin{array}{l}\text { Odsetek } \\
\text { zatrudnionych na } \\
\text { obszarach } \\
\text { wiejskich (\%) }\end{array}$} & $\mathrm{N}$ & 1 & 8 & 8 & 8 & 25 \\
\hline & Średnia & 34,57 & 6,80 & 44,26 & 26,09 & 26,07 \\
\hline & Współczynnik zmienności & & $54,3 \%$ & $25,6 \%$ & $29,3 \%$ & $65,9 \%$ \\
\hline & Rozstęp & 0,00 & 11,20 & 28,15 & 19,43 & 57,11 \\
\hline & Minimum & 34,57 & 0,63 & 29,59 & 17,27 & 0,63 \\
\hline & Maksimum & 34,57 & 11,83 & 57,74 & 36,70 & 57,74 \\
\hline
\end{tabular}




\begin{tabular}{|c|c|c|c|c|c|c|}
\hline \multirow{2}{*}{\multicolumn{2}{|c|}{ Oceniane zmienne }} & \multicolumn{5}{|c|}{ Grupy wyróżnione dla obszarów wiejskich } \\
\hline & & \multirow{2}{*}{$\begin{array}{ll}0 & \\
& 1\end{array}$} & \multirow{2}{*}{$\begin{array}{ll}1 & \\
& 8\end{array}$} & \multirow{2}{*}{$\begin{array}{|ll|}2 & \\
& 8 \\
\end{array}$} & \multirow{2}{*}{$\begin{array}{ll}3 & \\
& 8\end{array}$} & \multirow{2}{*}{$\frac{\text { Ogółem }}{25}$} \\
\hline \multirow{6}{*}{$\begin{array}{l}\text { Odsetek wartości } \\
\text { dodanej brutto } \\
\text { (GVA) na } \\
\text { obszarach } \\
\text { wiejskich }(\%)\end{array}$} & $\mathrm{N}$ & & & & & \\
\hline & Średnia & 34,00 & 5,27 & 35,36 & 19,87 & 20,72 \\
\hline & Współczynnik zmienności & & $58,8 \%$ & $24,5 \%$ & $32,2 \%$ & $67,4 \%$ \\
\hline & Rozstęp & 0,00 & 8,61 & 23,74 & 16,82 & 48,67 \\
\hline & Minimum & 34,00 & 0,55 & 25,48 & 12,01 & 0,55 \\
\hline & Maksimum & 34,00 & 9,16 & 49,22 & 28,83 & 49,22 \\
\hline
\end{tabular}

Źródło: opracowanie własne na podstawie EUROSTAT 2018.

Analizę taksonomiczną przeprowadzano w oparciu o cztery przedstawione powyżej wskaźniki oraz indeksy ich zmiany $\mathrm{w}$ okresie badania, a do oceny podstaw zróżnicowania wyłonionych skupień wykorzystano technologię drzew klasyfikacyjnych i regresyjnych (C\&RT). Metodologia ta umożliwia ustalenie wagi poszczególnych zmiennych dla dokonanego grupowania. W tabeli 7 zaprezentowano wage poszczególnych predykatorów $\mathrm{w}$ procesie dyskryminacji wyodrębnionych grup taksonomicznych. Oszacowania wskazują na dominująca rolę w tym zakresie cech zaprezentowanych $\mathrm{w}$ tabeli 6 . Metoda drzew klasyfikacyjnych sugeruje, że najważniejszym wyróżnikiem jest odsetek obszarów wiejskich. Natomiast pozostałe trzy cechy maja porównywalny, ale mniejszy wpływ na rozróżnienie między grupami. Indeksy zmian dla rozpatrywanych zmiennych dyskryminują skupienia w znacznie mniejszym zakresie. Najważniejszym z nich jest „Zmiana udziału zatrudnionych na obszarach wiejskich”, a najmniej oddziałującym „Zmiana udziału obszarów wiejskich w tworzeniu wartości dodanej brutto".

Tabela 7 Ważność predyktorów w procesie dyskryminacji przynależności do grup wyróżnionych dla obszarów wiejskich metodą drzew klasyfikacyjnych i regresyjnych (C\&RT)

\begin{tabular}{|l|r|r|}
\hline \multicolumn{1}{|c|}{ Zmienna } & Ranga & Ważność \\
\hline Odsetek powierzchni obszarów wiejskich (t_RUR) & 100 & 1,000 \\
\hline Udział ogółu zatrudnionych na obszarach wiejskich (e_RUR) & 76 & 0,760 \\
\hline Odsetek ludności zamieszkującej na obszarach wiejskich (p_RUR) & 76 & 0,760 \\
\hline Udział obszarów wiejskich w tworzeniu wartości dodanej brutto (G_RUR) & 76 & 0,760 \\
\hline Zmiana udziału zatrudnionych na obszarach wiejskich (v_eR) & 39 & 0,391 \\
\hline Zmiana udziału ludności na obszarach wiejskich (v_pR) & 29 & 0,294 \\
\hline Zmiana powierzchni obszarów wiejskich (v_tR) & 27 & 0,268 \\
\hline $\begin{array}{l}\text { Zmiana udziału obszarów wiejskich w tworzeniu wartości dodanej brutto } \\
\text { (v_GR) }\end{array}$ & 12 & 0,124 \\
\hline
\end{tabular}

Źródło: opracowanie własne na podstawie EUROSTAT 2018

Istotę wpływu zmiennych będących podstawą formowania skupień metodą taksonomiczną na ich ostateczny kształt odzwierciedla struktura drzewa klasyfikacyjnego przedstawiona na rysunku 2.

Ukazuje ona, że w pierwszej kolejności wyróżnione grupy różnią się najbardziej ze względu na udział obszarów wiejskich w tworzeniu wartości dodanej brutto. Kraje grupy pierwszej cechują się niskim odsetkiem wartości dodanej brutto (węzeł 2: poniżej $10,6 \%)$. 


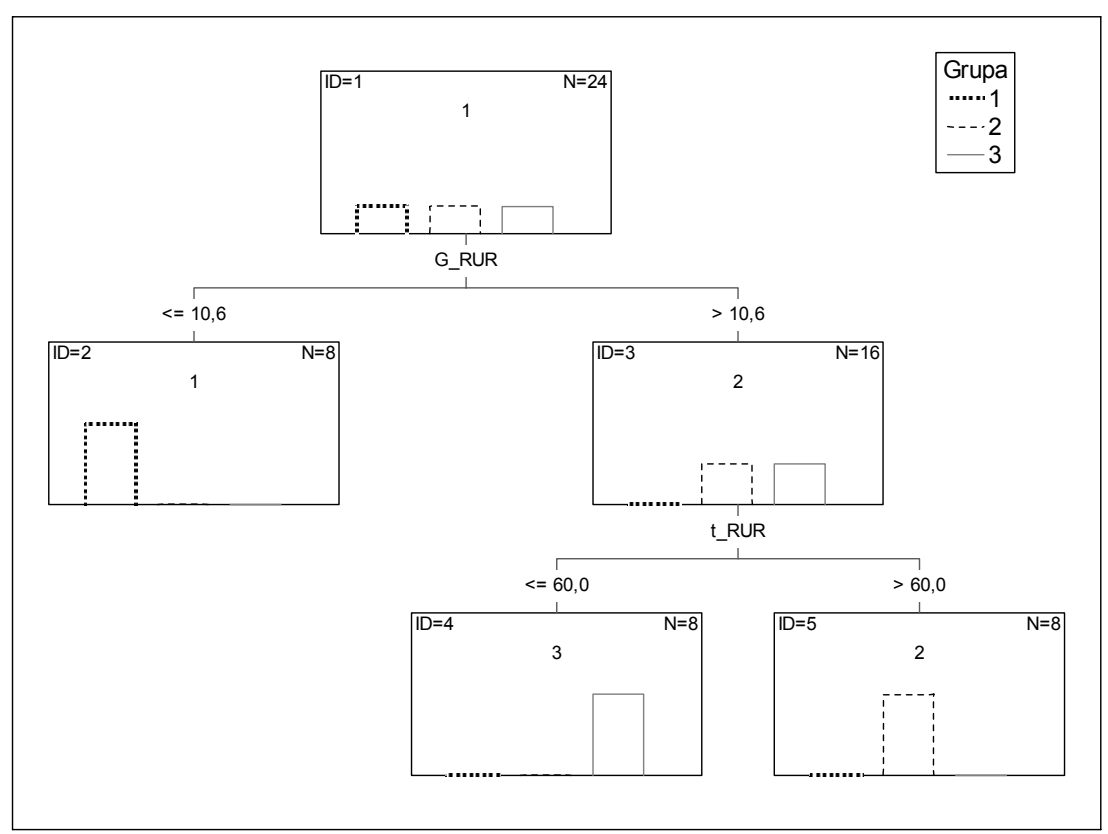

Rysunek 2. Dyskryminacja przynależności do grup wyróżnionych dla obszarów wiejskich (metoda drzew klasyfikacyjnych i regresyjnych C\&RT)

Źródło: opracowanie własne na podstawie EUROSTAT 2018.

Pozostałe państwa zakwalifikowane do węzła 3 w największym stopniu są różnicowane ze względu na udział terytorialny obszarów wiejskich. Na kolejnym etapie węzeł ten jest dzielony na podgrupę o wartościach wskaźnika poniżej 60\% (skupienie trzecie) oraz podgrupę, w której udział obszarów wiejskich w tendencji przekracza 60\% (skupienie drugie).

\section{Podsumowanie}

Podział obszarów wiejskich w krajach Unii Europejskiej na trzy kategorie delimitacji, tj. obszary wiejskie, pośrednie (wiejsko-miejskie) i miejskie ma charakter sformalizowany i stanowi podstawę ich klasyfikacji w statystykach EUROSTAT. Przeprowadzone badania obejmowały analizy i oceny zróżnicowania oraz wielowymiarowość i znaczenie powyżej wskazanych dwóch kategorii wiejskości. Dla wybranych czterech zmiennych opisujących; powierzchnię obszarów wiejskich, udział ludności, udział zatrudnionych i udział w wypracowanej wartości dodanej brutto (GVA) wykonano analizy tabelaryczne, analizę skupień oraz dokonano typologii wyróżnionych grup krajów przy zastosowaniu techniki drzew klasyfikacyjnych.

Przeprowadzone badania wskazały na wielowymiarowe zróżnicowanie obszarów wiejskich oraz ich duże, a nawet dominujące, znaczenie w gospodarce poszczególnych krajów. Na wydzielonych stricte obszarach wiejskich krajów UE, które stanowią 44,14\% powierzchni lądowej, zamieszkuje 19,24\% ludności. Największą powierzchnię obszarów wiejskich ma Francja i Finlandia (odpowiednio 340,82 tys. km i 278,88 tys. $\mathrm{km}^{2}$. 
Natomiast największy udział obszarów stricte wiejskich wykazują takie kraje jak: Irlandia, Finlandia i Estonia tj. odpowiednio 90,0, 82,4 i 81,6\%. Na przeciwnym biegunie tego podziału jest Holandia (2,1\%), Litwa $(13,6 \%)$ i Hiszpania $(16,9 \%)$. Na obszarach wiejskich krajów UE zamieszkuje 97,8 mln mieszkańców, tj. 19,2\% mieszkańców UE, a na obszarach wiejskich i pośrednich 55,3\%. Największy udział ludności mieszkającej na obszarach wiejskich wykazuje Irlandia $(60,7 \%)$ i Rumunia (53,9\%). Z kolei najmniejszy udział tej kategorii analitycznej odnotowano w Holandii (0,6\%) i Hiszpanii (3,5\%). Na obszarach stricte wiejskich zatrudnionych jest 18,9\% ludności aktywnej zawodowo, a na obszarach wiejskich i pośrednich 54,4\%. Powyżej 50\% ludności znajduje zatrudnienie na obszarach wiejskich, a takich krajów jak Słowenia (57,7\%), Irlandia (57,2\%) i Rumunia (54,9\%). Jednakże na obszarach wiejskich wytwarza się tylko 13,0\% wartości dodanej brutto (GVA), a na obszarach wiejskich i pośrednich 43,6\%. Pod względem udziału GVA wypracowanej na obszarach wiejskich dodatnio wyróżniają się takie kraje jak Słowenia $(49,2 \%)$ i Irlandia (46,5\%), a najmniejszy udział odnotowano w Holandii (0,5\%), Wielkiej Brytanii (2,6\%) oraz Hiszpanii (3,1\%).

Analiza skupień przeprowadzona dla ośmiu zmiennych - tj. czterech analizowanych powyżej wskaźników charakteryzujących obszary wiejskie oraz indeksy ich zmian w okresie badania - pozwoliła na wyodrębnienie trzech homogenicznych grup państw. Polska oraz kraje, jak: Czechy, Dania, Francja, Łotwa i Niemcy znalazły się w skupieniu trzecim. Czynnikiem najsilniej różnicującym obszary wiejskie w krajach UE jest udział ich powierzchni w ogólnej powierzchni kraju. Najwyższym odsetkiem obszarów wiejskich (76,85\%) oraz najniższym zróżnicowaniem wyróżnia się skupienie drugie (Austria, Estonia, Finlandia, Grecja, Irlandia, Portugalia, Rumunia i Słowenia). Kontrastowo, w grupie tej stosunkowo niski jest udział wartości dodanej brutto (GVA) wytwarzanej na obszarach wiejskich (35,36\%). Odmiennie, w grupie pierwszej (Belgia, Bułgaria, Hiszpania, Holandia, Litwa, Szwecja, Wielka Brytania oraz Włochy) ze średnim 20,7\% udziałem obszarów wiejskich występują najniższe wartości poszczególnych cech oraz ich najwyższe zróżnicowanie. Grupy druga oraz trzecia posiadają podobne struktury rozpatrywanych wskaźników, jednak wartości cech są wyraźnie niższe w skupieniu trzecim.

\section{Bibliografia}

Czarnecki A. Rola urbanizacji w wielofunkcyjnym rozwoju obszarów wiejskich. Seria: Problemy rozwoju wsi i rolnictwa. IRWIR PAN, Warszawa 2009, s. 21-27.

Dijkstra Lewis, Poelmann Hugo, Remote Rural Regions - How proximity to a city influences the performance of rural regions, DG Regio, European Commission, Brussels 2008

Dijkstra Lewis, Ruiz Vicente. Refinement of the OECD regional typology: Economic Performance of Remote Rural Regions, DG Regio, European Commission, Brussels. 2010.

Hand D., Mannila H., Smyth P. Eksploracja danych. Wydawnictwa Naukowo-Techniczne, Warszawa 2005.

Kaleta A. Obszary wiejskie i koncentracje jego rozwoju. W: Rozwój obszarów wiejskich w perspektywie integracji z UE. FAPA, UMK, SGGW, Torun 1998.

Koronacki J., Ćwik J. Statystyczne systemy uczqce się. Exit, Warszawa 2008.

Kostrowicki J. Obszary wiejskie jako przestrzeń wielofunkcyjna. Zagadnienia badawcze $i$ planistyczne. Przegląd Geograficzny 1976, z. XLVII z. 4

Larose D.L. Odkrywanie wiedzy z danych, wprowadzenie do eksploracji danych. Wydawnictwo Naukowe PWN, Warszawa 2007.

Marek T. Analiza skupień w badaniach empirycznych. Metody SAHN. PWN, Warszawa 1989. 
Rosner A. Zmiany rozkladu przestrzennego zaludnienia obszarów wiejskich. Wiejskie obszary zmniejszajace zaludnienie $i$ koncentracje ludności wiejskiej. Seria: Problemy rozwoju wsi i rolnictwa. IRWIR PAN, Warszawa 2012, s. 53-64.

Rural Development in the EU. Statistical and Economic Information Report 2013, European Commission, Brussels.

Sroka W., Musiał W. Rolnictwo i gospodarstwa rolne na obszarach miejskich $i$ podmiejskich. Konceptualizacja oraz przestanki rozwoju Folia Pomerania, Oeconomica 2016, 329(84)3, 123-134.

Stanny M. Poziom rozwoju obszarów wiejskich w Polsce - pomiar zjawiska złożonego. W: Rozwój wsi i rolnictwa w Polsce. Aspekty przestrzenne i regionalne red. Nauk A. Rosner. Seria: Problemy rozwoju wsi i rolnictwa. IRWIR PAN, Warszawa 2012, s. 93-100

Wilkin J. Ewolucja paradygmatów rozwoju obszarów wiejskich. Wieś i Rolnictwo 2008, (3) 140.

Zawalińska K. Instrumenty $i$ efekty wsparcia Unii Europejskiej dla regionalnego rozwoju obszarów wiejskich w Polsce. Seria: Problemy rozwoju wsi i rolnictwa. IRWIR PAN, Warszawa, 2009, s. 26-36.

\section{Summary}

The study undertakes the problem of identifying, cataloguing, and evaluating rural areas and intermediate areas of European Union countries, for four selected variables which describe: area, share of population, share of employed, and share of gross value added (GVA). Tabular analyses and cluster analysis ware conducted, and the statistical information was differentiated through classification trees. The research revealed multidimensional diversification of rural areas and their meaningful, although diverse, relevance within the economic systems of individual countries. $34,7 \%$ of the EU population reside in strictly rural areas, which make up $49,7 \%$ of the EU geographic area. The share of employed in rural areas in the EU amounts to $26,7 \%$. Additionally, the contribution of the rural areas to elaborated gross value added adds up to $13 \%$. The taxonomy resulted in the extraction of three groups (clusters), each containing eight countries. According to that comprehensive evaluation of rural areas, Poland is similar to the Czech Republic, Denmark, France, Latvia and Germany.

Key words: EU rural areas, population of rural areas, employment on rural areas, gross value added (GVA)

JEL Codes: Q18, R14, Q15

\section{Informacja o autorach:}

Dr hab. Strojny Jacek

Uniwersytet Rolniczy im. Hugona Kołłąaja w Krakowie

Wydział Rolniczo-Ekonomiczny

Katedra Statystyki i Polityki Społecznej,

Al. Mickiewicza 21

31-120 Kraków

e-mail: rrstrojn@cyf-kr.edu.pl

ORCID: 0000-0002-0577-377X

\section{Prof. dr hab. Wiesław Musial}

Uniwersytet Rolniczy im. Hugona Kołłątaja w Krakowie

Wydział Rolniczo-Ekonomiczny

Katedra Ekonomii i Gospodarki Żywnościowej

Al. Mickiewicza 21

31-120 Kraków

e-mail: wieslaw.musial@urk.edu.pl

ORCID: 0000-0002-8213-4859 